\title{
MUSLIM INTELLECTUALS IN THE TWENTIETH CENTURY INDONESIA A Socio-political and Educational Context ${ }^{1}$
}

\author{
Khoirun Niam \\ IAIN Sunan Ampel, Surabaya, Indonesia
}

\begin{abstract}
Various criteria have been formulated to determine whether or not someone should be classified as an intellectual. These criteria range from patterns of recruitment to responses to various cultural or political movements. This paper is devoted, however, to examining the rise of Muslim intellectuals in Indonesia in the last three decades of the twentieth century. It highlights, as a subject of analysis, the significance of socio-political (and even religious) context as well as the educational background upon which the formation of those Indonesian Muslim intellectuals is based. An important finding shows that the rise of Indonesian Muslim intellectuals in such a time frame resulted mainly from three vectors, movements in Islamic thought, socio-political relations between the government and the Muslim community, and developments in education. The educational background of Muslim intellecttuals, as another finding encapsulates, is not monolithic since some of them pursued their studies in Islamic educational institutions, and some others in more general, public ones.
\end{abstract}

Keywords: Muslim intellectual, the renewal of Islamic thought, government-Muslims relation, Muslim student movement.

\footnotetext{
${ }^{1}$ This paper is originally part of my $\mathrm{PhD}$ dissertation entitled Muslim Intellectuals in Contemporary Indonesia: Survey of Muslim Intellectual Institutional Affiliation and Thought (1966 -2001) submitted to the Faculty of History and Cultural Studies, Freie Universität, Berlin, Germany, in 2003. I am grateful for the comments of Gudrun Krämer, Ingrid Wessel, Ulrike Freitag, Axel Havemann, Stephan Rosiny and Akh. Muzakki on an earlier version of this paper.
} 


\section{Introduction}

One of the most important debates among scholars is whether, in playing a role in society, intellectuals should or should not be affiliated with certain institutions. There are at least two opinions on this matter. First, intellectuals should not be affiliated with any institutions. Second, intellectuals should be affiliated with institutions. The first opinion is promoted in order to guarantee the independence of intellectuals in criticising and directing society. In accordance with Brym's idea, this opinion argues that intellectuals will lose their independence through employment in the institutional superstructure. ${ }^{2}$ Presenting themselves as independent intellectuals, or referred to in the Coser's phrase as "unattached intellectuals", 3 "they may continue to provide some of the major critical ideas that will later spread to a wider public and to public decision-makers, and they may continue to help set standards and influence ideological trends". According to Coser, "they are in a privileged position to do so because they are less restrained by institutional pressures, more mobile because of their freedom from institutional roots, less subject to regular obligations and routines than are other categories of intellectuals". 4

For many observers, a critical and progressive attitude is the most important characteristic in which someone could be categorized as intellectual or not. ${ }^{5}$ Concerning politics, for example, the power of intellectuals is sometimes used to justify the government's power and decision. This could eliminate intellectual independence and influence. ${ }^{6}$

\footnotetext{
2 See, Robert J. Brym, Intellectuals and Politics (London: Goerge Allyn and Unwin, 1980), p. 12. An example in an Indonesian context is what was reflected in the case of Emha Ainun Najib, the chairman of the Department of Cultural Dialogue of the Ikatan Cendekiawan Muslim se-Indonesia (ICMI/the Association of Indonesian Muslim Intellectuals, established in 1990), who quitted the Central Board of the ICMI in August 1991 because he was not satisfied with the political line taken by the organization. For further information in this case, see Editor (Weekly News), 14 March 1992. See also Darul Aqsha, Dick van der Meij, and Johan Hendrik Meuleman (eds.), Islam in Indonesia: A Survey of Events and Developments from 1988 to March 1993 (Jakarta: INIS, 1995), p. 267.

${ }^{3}$ A. Lewis Coser, Men of Ideas (New York: London, 1965), especially pp. 263 - 274.

${ }^{4}$ Ibid., p. 273.

${ }^{5}$ Brym, Intellectuals and Politics, p. 12.

${ }^{6}$ In many cases, the legitimacy of intellectuals to the power is needed and politically right. As described by Coser, there are two kinds of legitimacy in this case: first is that intellectuals may fashion new legitimacies in historical situations in which the old ones
} 
For this reason, there are people who believe that it is important to ensure the independence of intellectuals from institutions. But, the consequence of this could lead intellectuals to an "ivory tower" condition.

The second opinion recommends that intellectuals should be affiliated with institutions. The advocates of this opinion worry that intellectuals could not play their role directly and even exclude themselves from society if they are not affiliated with a certain institution. In line with this idea, Brym argues that intellectuals should understand their positions in society. He said in his book, Intellectuals and Politics: "intellectuals in the modern world had to come to grips with the question to which class (if any) they belonged and to which political current they adhered." 7

As reflected in the experience of many countries, the involvement of intellectuals is needed, especially —-borrowing Shils' word-“in the gestation, birth, and continuing life of the new states", such as in Asia and Africa. ${ }^{8}$ Moreover, in developed countries, intellectuals are being absorbed into rapidly expanding and increasingly state directedinstitutional superstructures. ${ }^{9}$ In the United States, for example, as described by Coser, "intellectuals are located in a great variety of institutional settings as well as in the interstices between a numbers of institutional orders." 10 With similar arguments, the involvement of

no longer seem sufficient to shore up the edifice of power, or they may create entirely novel systems of legitimacy in order to justify new systems of power. This kind of thought is categorized as conservative thought. Second is that intellectuals create a justification mechanism for a new system of power. As a new power was established or seized by a new revolutionary-intellectual government, the intellectuals are needed for the defense against those who disputed the legitimacy of the power. For a further description of such intellectuals, see Coser, Men of Ideas, pp. 140-142, and pp. 189-205.

7 Brym, Intellectuals and Politics, p. 11.

${ }^{8}$ Compare with Edward Shils' idea in his article 'The Intellectuals in Political Development of the New States" in Jason L. Finkle and Richard W. Gable (eds.), Political Development and Social Change (New York: London, 1971), p. 249, where he said that "the gestation, birth, and continuing life of the new states of Asia and Africa, through all their vicissitudes, are in large measure the work of intellectuals. In no state-formations in all of human history have intellectuals played such a role as they have in these events of the present century".

${ }^{9}$ Brym, Intellectuals and Politics, p. 12.

${ }^{10}$ See Coser, Men of Ideas, p. 249. 
intellectuals in society or even in political leadership is badly needed in the context of developing countries.

This paper is not much about the debate concerning what intellectuals should do in dealing with the issue of intellectual-cumorganisational affiliation. Rather, it is devoted to examining the rise of Muslim intellectuals in Indonesia even though the addressing of the issue of organisational affiliation of those Muslim intellectuals will also be conducted in parts of its analysis. The paper highlights, as a subject of analysis, the significance of socio-political (and even religious) context as well as educational background upon which the formation of those Indonesian Muslim intellectuals is based. As a focus of analysis, the paper is restricted to the time frame in the last three decades of the twentieth century.

\section{The Emergence of Muslim Intellectuals:}

\section{A Socio-political Context}

As a starting point for analysing the rise of Muslim intellectuals in the last three decades of the twentieth century, let us look at some important aspects concerning what happened to educated Muslims and organizations of Muslim scholars before 1970. M. Dawam Rahardjo describes in his book Intelektual, Intelegensia dan Perilaku Politik. Bangsa ${ }^{11}$, that in 1964 an organization for Muslim scholars called Ikatan Sarjana Muslim Indonesia (ISMI/the Association for Indonesian Muslim Scholars) was established. ISMI was established in response to the existing political and ideological competition and conflict against communism and the left wing nationalist movement. ${ }^{12}$

Another similar organization was established by H.M. Subchan Z.E in 1969; its name was Persatuan Sarjana Muslim Indonesia

\footnotetext{
11 The book was published in 1993, three years after the establishment of the ICMI, which he played an important role in founding processes. During my interview with Dawam Rahardjo (Jakarta, 24 August 2000), I could not get any information about the historical dynamic of Muslim intellectuals, especially during the 1960s. What he told me was the historical background of ICMI's founding in 1990. Therefore, I used his book for further historical exploration.

12 In the context of socio-political development in 1990, ISMI was suggested by Nurcholish Madjid to be the name of the Association of Muslim scholars later known as ICMI. For a further explanation of this, see Robert W. Hefner, "Islam, State and Civil society: ICMI and the Struggle for Indonesian Middle Class," Indonesia, No. 56 (1993), p. 1; Greg Barton, Gagasan Islam Liberal di Indonesia (Jakarta: Paramadina, 1999), p. 506.
} 
(Persami/the Union of Indonesian Muslim Scholars). The establishment of Persami aimed to unite Muslim scholars from different political parties and religious groups. Under the leadership of Bintoro Tjokroamidjojo, Persami attempted to improve the participation of Muslim scholars in the development processes promoted by the New Order government. Unlike ISMI which was developed in response to the existing political and ideological conflict as indicated above, Persami was founded as a reaction towards a new situation, namely the development program. ${ }^{13}$

Despite their varied organisational affiliations, many Muslim scholars from the 1970s generation went to study in Western countries. Three people can be mentioned as examples, and just by chance they graduated from the same university (The University of Chicago): Nurcholish Madjid (1939-2005), M. Syafi'i Maarif (born in 1935), and M. Amien Rais (born in 1944). Many others went to study in the Middle Eastern countries, such as Abdurrahman Wahid (born in 1940), while still others graduated from Indonesian universities, including M. Dawam Rahardjo (born in 1942).

There are three important activities which became preconditions for the rise of Muslim intellectuals. First, there emerged a critical analysis formulated through the writing of articles or the presenting of ideas in seminars or discussion forums. Second, there developed ideas for constructing a model of societal improvement. Third, there was an innovation in professional works in different fields such as medicine, societal health, education, management, accountancy, journalism, and law.

In addition to that, there was a wide range of efforts to translate and advance Western and Middle Eastern intellectual ideas. In the 1980s particularly after the Iranian Revolution, attempts to introduce a large number of 'Ali Shariati's works (mostly discussing revolution, social change, and the role of Muslim intellectuals), for example, were conducted into Indonesian readers. Following Madjid's return to Indonesia, Maarif also introduced Fazlur Rahman's ideas of neomodernism. Ismāail Farūqi, Hassan Hanafi, Ziauddin Sardar, and Murtada Mutahhari were among other foreign Muslim intellectuals whom Indonesian Muslims intellectuals referred to and whose ideas

13 M. Dawam Rahardjo, Intelektual, Intelegensia dan Prilaku Politik Bangsa (Bandung: Mizan, 1993), pp. 23-24. 
were introduced. ${ }^{14}$ To a certain extent, their ideas influenced the intellectual character of Indonesian Muslims and even influenced the model of Islamic thought in Indonesia.

What were then the important factors that influenced the emergence of Indonesian Muslim Intellectuals in the 1970s and 1980s? First was the result of the renewal of the Islamic thought movement promoted by scholars such as Madjid, Harun Nasution, and Mukti Ali. Second was the consequence of social and political relations between the government and the Muslim community during the New Order era. Third was a fruit of the development of education and of Muslim student movement.

As described by many researchers such as Greg Barton, Robert W Hefner, Muhammad Kamal Hasan and M. Syafii Anwar, the renewal of the Islamic thought movement in Indonesia can be understood through two important points. First, the renewal of Islamic thought was introduced by Madjid in the beginning of 1970. Second, the renewal of Islamic thought was promoted by the "Limited Group" in Yogyakarta.

The Limited Group, founded in the middle of 1967, was composed of several students, including mainly Ahmad Wahib, Djohan Effendi, and Rahardjo. The group met in the on-campus house of Mukti Ali, a leading lecturer of the Institut Agama Islam Negeri (IAIN/State Institute for Islamic Studies) who later became the Minister of Religious Affairs. In addition to the regular core members, a wide variety of intellectuals, students and activists, Muslim and nonMuslim, dropped in for "closed door" discussions on religious, moral and philosophical issues. The ideas produced by the Limited Group, including the turning ummah (Muslim community) away from party political activity and the strengthening of the non-sectarian state philosophy of Pancasila, unfortunately, attracted a very poor public attention at the time. According to Barton, the reason is that until the publication Wahib's diary and private writings in 1981,15 there was little in print to document what might be called the genesis of neomodernism (in this case referring to the renewal of Islamic thought) in Indonesia.

\footnotetext{
14 Ibid., pp. 25-26.

15 The book was edited by his friends, Djohan Effendy and Ismet Natsir, under the title: Pergolakan Pemikiran Islam, Catatan Harian Abmad Wabib (Jakarta: LP3ES, 1981).
} 
In contrast with the Limited Group, the renewal of Islamic thought promoted by Madjid attracted the attention of not only the public in general but also Muslim intellectuals specifically at that time. This began with Madjid's address on the $3^{\text {rd }}$ of January 1970. Madjid suggested two important steps, namely modernization and secularization. In his opinion, modernization means tearing down an irrational system of thought and work and replacing it with a rational one, because Alla orders us to always use our reason. Modernization is an order of God and fundamental to Islamic doctrine. ${ }^{16}$ "Modernization is rationalization" Madjid said. It is closely related to secularization. What is meant by secularization here is not an implementation of secularism but a "liberating development": secularizing what originally should be secular and liberating Muslims from assuming it as a religious matter. ${ }^{17}$

This idea led to the emergence of many critiques from other Muslim Intellectuals. Some of them came from the older generation, such as M. Natsir, Subchan ZE and M. Rasyidi. Rasyidi, for example, made his critique in his book Koreksi terhadap Drs. Nurcholish Madjid tentang Sekularisasi [Correction to Nurcholish Madjid about Secularization]. ${ }^{18}$ Natsir criticised the renewal of Islamic thought by Madjid, not only for being irrelevant but also for becoming a danger to the Islamic essence. ${ }^{19}$ Subchan ZE argued that the renewal of Islamic thought is not necessary because Islam is a complete religion. If there is a renewal effort, he further argues, it should avoid changing "aqidab". ${ }^{20}$

Apart from critiques as such, Madjid's view has continuously had its place and influence. His view has frequently become the main theme of many mass media. Tempo, a weekly magazine, for example, intensively echoed Madjid's views. M. Deden Ridwan writes that he has found many volumes of this magazine which had Madjid's views as

${ }^{16}$ Nurcholish Madjid, Islam, Kemoderenan dan Keindonesiaan (Bandung: Mizan, 1995), p. 172.

17 See Ibid., p. 201.

${ }^{18}$ M. Rasyidi, Koreksi terhadap Drs. Nurcholish Madjid tentang Sekularisasi (Jakarta: Bulan Bintang, 1972).

19 Tempo, 29 July 1972, p. 45. See also M. Deden Ridwan, "Tempo dan Gerakan NeoModernisme Islam Indonesia," Ulumul Quran, No. 3, Vol. VI (1995), pp. 56-57.

${ }^{20}$ Ridwan, “Tempo dan Gerakan Neo-Modernisme." 
its main topic, specifically Tempo's volumes of May 1971, April 1971, July 1972, December 1972, January 1973, June 1986, and April 1993. ${ }^{21}$ In the June 1986 edition, Tempo stressed that after fifteen years, the history stood side by side with Madjid's view. As a result, Indonesian people has not worried anymore to actualize Islamic values and to say that they are Muslims without any eagerness of being correlated with the Islamic state movement or Islamic party. 22

The pioneering Madjid's activity in promoting the importance of renewing Islamic thought in Indonesia gave rise to two consequences. First is that the renewal idea inspired other Muslim intellectuals to criticise it. Second is that this idea caused the emergence of a new generation of young Muslim intellectuals who stood behind Madjid's ideas.

Besides Madjid, Nasution (born in 1919) also played an important role in promoting the importance of renewing Islamic thought. The difference is that while Madjid, because of his involvement in the Muslim Student Association, had many supporters and therefore his idea was publicly known, Nasution directed his ideas toward the educated Muslim elites. In other words, Nasution expressed his ideas primarily for people affiliated with educational institutions such as IAIN, Institut Keguruan dan Ilmu Pendidikan (IKIP/Teachers Training Collage), and the University of Indonesia (UI) in Jakarta.

Acknowledged as a mujaddid and a reformer in Islamic theology, ${ }^{23}$ Nasution has had an impact on what Madjid called the intellectual creativity and learning capacity of IAIN. ${ }^{24}$ He successfully opened the gates for academic people in IAIN to think rationally. He rendered his academic institution many services. One of them was orienting the curriculum of IAIN not merely to figh (Islamic jurisprudence) studies but also to philosophy, and the comparative studies between schools of law. In addition, he also successfully brought IAIN to the same level as other higher educational institutions. Under his leadership, IAIN

\footnotetext{
21 Ibid., p. 52. Further evidence of the importance of Madjid's view is that "Jurnal Ulumul Quran" published this issue twice: in Number 1, vol. IV (1993) and Number 3, vol. VI (1995).

22 Ridwan, “Tempo dan Gerakan Neo-Modernisme,” p. 52.

23 Panitia Penerbitan Buku dan Seminar 70 Tahun Harun Nasution, Refleksi Pembaharuan Pemikiran Islam (Jakarta: LSAF, 1989), pp. 267-268.

${ }^{24}$ Ibid., p. 103.
} 
created a post-graduate program that produced many highly educated Muslims. ${ }^{25}$

In connection with the factor of government-Muslims relation, the Indonesian government at the beginning of the New Order era intended to achieve state security and political stability. ${ }^{26}$ As a result, the government hoped that it could concentrate on development activities. With this intention, it minimized the number of existing political parties. Suharto's government persistently believed that the conflicting ideologies represented by the political parties were responsible for the political chaos in 1965 . Therefore, a request by Muslims to rehabilitate the Masyumi, the largest modernist Islamic political party which was banned by Soekarno in 1960, was not granted for fear of a return of old party politicians. Instead, permission was granted to form a new Islamic party called Partai Muslimin Indonesia (the Parmusi) but only with junior ex-Masyumi leadership. This apparently caused Muslim political disappointment with Suharto's policy towards Islam. ${ }^{27}$

There was a varied kind of Muslims' responses towards such a New Order's policy. First, there was a formalist response. This response saw that it was necessary to follow formal efforts in constructing the ideals of political Islam. For this formalist group, the goal of political Islam could only be achieved if the Islamic ummah were a legally acknowledged political party. The existence of an Islamic party was necessary as a tool for competing in politics, religion and inter-ideological groups. Second, there were Muslim groups who gave priority to the integrity of Muslim ummah but did not agree with their involvement in politics. For this group, the integrity of Muslim ummah was more important than practical political needs. Politics is usually shadowed by conflicts of interest and therefore would lead to

${ }^{25}$ For further information about intellectual development in IAIN see "Intellectual Engineering in IAIN," a supplementary article in Studia Islamika, Vol. 2, Number 1 (1995), pp. 1-7.

26 Azyumardi Azra, Esei-esei Intelektual Muslim dan Pendidikan (Jakarta: Logos, 1998), p. 62.

${ }^{27}$ Muhammad Atho' Mudzhar, Fatwas of the Council of Indonesian Ulama: A Study of Islamic Legal Thought in Indonesia (1975-1988) (Jakarta: INIS, 1993), p. 50. See also Greg Barton, "Indonesia's Nurcholish Madjid and Abdurrahman Wahid as Intellectual Ulama: The Meeting of Islamic Traditionalism and Modernism in Neo-Modernist Thought, Islam and Christian-Muslim Relation," Studia Islamika, Vol. 8, No. 3 (1997), p. 325. 
disintegration in the Muslim ummah. Third, there was a pragmatic response, seeing the earlier two approaches as too idealistic and not pragmatic. The supporters of such two approaches are always criticised for the leadership of the old political party activists who failed to promote the development efforts within Muslim ummah. This third group tends to choose an accommodative approach in response to the existing social and political development. ${ }^{28}$

In addition, as noted by Hefner, there were Muslim intellectuals who always took a less pessimistic view of the New Order government. They insisted that restrictions on "political Islam" in the sense of Islamic political parties which aimed to capture the reins of government should not be equated with government opposition to "culture" or "civil" Islam, which is to say, a kind of Islam whose primary role in the life of the nation is to serve as a source of ethical and cultural guidance. In the late 1960s, this optimistic view of government-Muslim relations was advocated by a number of young Muslim intellectuals, including Usep Fatchuddin and Utomo Danandjaja from the Pelajar Islam, Wahib, Rahardjo, and Efendi from the "Limited Group" discussion circle in Yogyakarta, and Madjid from the Jakarta headquarters of Himpunan Mabasiswa Islam (HMI/Islamic Students' Organization).

As alumni of Islamic student movement in 1965-1966, those young Muslim intellectuals as such were neither dependent on nor committed to the party organizations of the 1950s. Hence, in the face of continuing government restrictions on political parties in the late 1960s, they distanced themselves from mass politics in favour of a new strategy of Islamic revitalization. They were convinced that a long-term cultural approach to Islamic revitalization had to be formulated in such a way that it is capable of neutralizing military concerns while slowly deepening the roots of Islam in the nation as a whole. ${ }^{29}$

In 1975-1979 there were significant changes in the government policy. Hefner argues that the government, despite controlling political Islam, experienced an important change, as a segment of the ruling elite began to recognize the need for a more sympathetic

\footnotetext{
28 M. Syafi'i Anwar, Pemikiran dan Aksi Islam Indonesia: Sebuah Kajian Politik tentang Cendekiawan Muslim Orde Baru (Jakarta: Paramadina, 1995), pp. 45-46.

${ }^{29}$ Hefner, "Islam, State and Civil Society," pp. 4-5.
} 
accommodation of Muslim interests. In this matter, Hefner described that it can be seen in:

...the effort by the Departments of Religion and Education in expand the institutional foundation for Islamic education and dakwah (proselytization) throughout Indonesia. One important feature of this effort was the enormous expansion in State Islamic Institute Colleges (IAIN) which began in the 1960s and which, during the 1970s and 1980s, produced large numbers of graduates trained in Islamic theology, law, arts, and pedagogy. This expansion in Islamic higher education was accompanied by an even more impressive program of infra-structural development sponsored by the Department of Religion, focusing on the construction of mosques, prayer halls (mushalla), and Islamic schools (madrasah), especially in areas regarded as only weakly committed to Islam. ${ }^{30}$

The government also realised that the development efforts were less useful if Muslims did not engage in their processes. The government was aware that many problems facing the nation simply could not be solved without the participation of the 'ulama'>r Muslim scholars. Based on these reasons, the government supported the establishment of the Council of Indonesian 'Ulama' $>$ MUI) in 26 July $1975 .{ }^{31}$

The progress of cultural Islam, according to Hefner, was not matched in the political arena, however. The early 1980s saw, the government escalated its demand that all social and political organizations acknowledge the Pancasila as their "sole foundation," under so-called asas tunggal policy. The government's effort was deeply resented by Muslims. The policy had an especially devastating impact on Muslims, splintering an already fractured Muslim leadership, as disagreement broke out over the proper response to the government policy. 32

\footnotetext{
${ }^{30}$ Ibid., p. 10.

${ }^{31}$ For further information about MUI, see Majelis Ulama Indonesia, 20 Tabun Majelis Ulama Indonesia (Jakarta: MUI, 1995); "Majelis Ulama Indonesia", in Aqsha, Meij, and Meuleman (eds.), Islam in Indonesia, pp. 197-214; Mudzhar, Fatwas of the Council of Indonesian Ulama.

${ }^{32}$ Hefner, "Islam, State and Civil Society," p. 11.
} 
Despite the impact of this policy, according to Hefner, "many Muslim leaders regarded the 1980s as a decisive turning point for cultural and civil Islam and a vindication of the accommodative group's attitude toward the government. The great majority of Muslim intellectuals today believe that their acceptance of the asas tunggal policy had an important unintended consequence, which was that Islam was no longer associated with any single party." 33

Gradually there was a shift in perception of the relations between the government and Islam in Indonesia, which was the shift from strained relations to close relation. This was indicated by Muslim support of the government development and modernization programs. The government positively responded to Muslims' support by accommodating Islamic interests and involved Muslim ummah in the development process. From the above description, to sum up, it is clear that the dynamic relations between the government and the Muslim community affected the possibility of Muslims to look for positions, in which places were taken and in which role they should play. Ultimately, this condition was a benefit to the coming generation of Muslim intellectuals.

In addition to the factors of the rise of Muslim intellectuals in the 1970s and 1980s, the emergence of educated people in Indonesia cannot be separated from the improvement of the development programs in education. One of the developments in education was the increased budget for education and an increased number of participants in education (pupils and students). The budget for education that was allocated by the government, for example, indicated a significant change. In the Rencana Pembangunan Lima Tabun (Repelita/Five-Year Development Plan) II (1974/1975-1978/1979) the budget for education was 10.0 percent of the total national budget, and in Repelita III (1979/1980-1983/1984) the allocation was increased to 10.4 percent, and then increased again to 14.7 percent in Repelita IV (1984/1985-1988/1989). Based on this sort of data, Indonesia, as Anne Both from the Australian National University states, "has successfully brought about the revolution in education." 34 This policy increased the number of educated people in Indonesia.

33 Ibid., p. 11.

34 Anne Booth, "Repelita V and Indonesia's Medizm-term Economic Strategy," Prisma, Number 48 (December 1989), pp. 16-17, as quoted in Anwar, Pemikiran dan Aksi Islam Indonesia, pp. 115-116. 
The revolution of education stimulated increasing number of pupils and students, and most of them were santri or Muslims. The increasing number of educated people can be seen in the following table. ${ }^{35}$

Table 1 : Increases in the number of educated people in Indonesia from 1971 to 1985

\begin{tabular}{crrrrrr}
\hline Level of & \multicolumn{2}{c}{1971} & \multicolumn{1}{c}{1980} & \multicolumn{1}{c}{1985} \\
\cline { 2 - 7 } Education & \multicolumn{1}{c}{$\mathrm{N}$} & \multicolumn{1}{c}{$\%$} & \multicolumn{1}{c}{$\mathrm{N}$} & \multicolumn{1}{c}{$\mathrm{N}$} & \multicolumn{1}{c}{$\%$} \\
\hline SD & $75,061,921$ & 93.2 & $93,042,443$ & 89.2 & $100,627,003$ & 83.5 \\
SMP & $3,528,603$ & 4.5 & $6,236,461$ & 6.0 & $10,674,088$ & 8.9 \\
SMA & $1,645,164$ & 2.0 & $4,537,175$ & 4.3 & $8,140,790$ & 6.8 \\
PT & 271,388 & 0.3 & 508,173 & 0.5 & 938,574 & 0.8 \\
\hline Total & $80,507,076$ & 100.0 & $104,324,252$ & 100.0 & $120,380,485$ & 100.0 \\
\hline
\end{tabular}

Source: Biro Pusat Statistik as quoted by M. Syafii Anwar, Pemikiran dan Aksi Islam Indonesia: Sebuab Kajian Politik tentang Cendekiawan Muslim Orde Baru (Jakarta: Penerbit Paramadina, 1995), p. 116.

\section{Explanation:}

SD : (Sekolah Dasar/Elementary School)

SMP : (Sekolah Menengah Pertama/Lower Secondary School)

SMA : (Sekolah Menengah Atas/Upper Secondary School)

PT : (Perguruan Tinggi/Tertiary Education)

The table shows that the number of educated people in Indonesia significantly increased in the period of 1971-1985: the number of people who had graduated only from elementary school in 1971 reached 93.2 percent, and then decreased in 1980 to 89.2 percent, and further decreased again in 1985 to 83.5 percent. The number of people who had graduated only from lower secondary school in 1971 was 4.5 percent, and then in 1980 increased to 6 percent and to 8.9 percent in 1985. There were increasing numbers in the upper secondary school as well, from 2.0 percent in 1971 to 4.3 percent in 1980, and it increased again in 1985 to 6.8 percent. The people who graduated from tertiary education also showed an increasing number, from 0.3 percent in 1971 to 0.5 percent in 1980 , and it increased again in 1985 to 0.8 percent.

35 Mitsuo Nakamura, "The Emergence of an Islamizing Middle Class and the Dialectics of Political Islam in the New Order of Indonesia: Prelude to the Formation of ICMI," article for conference on "Islam and the Construction of Social Identity," University of Honolulu, 4-6 August 1993, p. 11, as quoted by Anwar, Pemikiran dan Aksi Islam Indonesia, p. 116. 
From this sort of data, it can be inferred that the proportion of educated people in Indonesia underwent the significant increase in the years 1971-1985.

Together with the increase in the number of educated people in Indonesia, the religious education also significantly improved. According to the statistical data, the total number of pupils in Madrasah Ibtidaiyah (MI/Islamic Elementary School) in 1980, from either state or private MIs was 2,941,383 or 14 percent of the total number of SD pupils in Indonesia. The number of total SD pupils in Indonesia was $21,165,742$. At the level of lower secondary education, the number of Madrasab Tsanawiyah (MTs/Islamic lower Secondary Education) was 340,156 , or 11 percent of total SMP pupils. At that time, the total was $2,894,983$.

In upper secondary education, the number of pupils in Madrasah Aliyah (MA/Islamic Upper Secondary School) was 93,840, or 9 percent of all SMA pupils which was 1,036,016. In the Pendidikan Guru Agama (PGA/Religious Teachers Training School), the number of pupils was 33.178. Its percentage in comparison to Sekolah Pendidikan Guru (SPG/Teacher Training School) was 15 percent of the total number of SPG pupils, which was recorded as 213,155 . In the tertiary education, the number of students at the Institut Agama Islam Negeri (IAIN/State Institute for Islamic Studies) was 28,122 or 14.3 percent of the total number of Indonesian students studying in state university institutions, which were 195,994 students. For further information, see the following table:

Table 2 : A comparison between pupils in general school institutions and pupils in Islamic school institutions in $\mathbf{1 9 8 0}$

\begin{tabular}{rrrr}
\hline $\begin{array}{r}\text { Level of } \\
\text { Education }\end{array}$ & General Education & Islamic Education & Percentage \\
\hline SD & $21,165,724$ & $2,941,383$ & 14 \\
SMP & $2,894,983$ & 340,156 & 11 \\
SMA & $1,036,016$ & 93,840 & 9 \\
SPG & 213,155 & 33,178 & 15 \\
PTN & 195,994 & 28,122 & 14.3 \\
\hline
\end{tabular}

Sources: Statistik Keagamaan 1980, Buku Saku Statistik Indonesia and Dhofier (1983) as quoted by Anwar, Pemikiran dan Aksi Islam Indonesia, p. 118. 
Explanation:

SPG : (Sekolah Pendidikan Guru/Teachers Training School)

PTN : (Perguruan Tinggi Negeri/State Tertiary Education)

The data presented in Table 2 show a large number of pupils and students at Islamic education institutions from the elementary to the tertiary level. This higher percentage has indicated, Zamakhsyari Dhofier writes, "a significant role in the intellectualization effort in Indonesia." 36

For further data on the growing numbers of educated people at Islamic education institutions in 1980, 1988, 1992, and 2000, the following table encapsulates the feature:

Table 3 : The growing numbers of educated people at Islamic education institutions in 1980, 1988, 1992, and 2000

\begin{tabular}{crrrr} 
Level of & 1980 & 1988 & 1992 & 2000 \\
Education & & & & \\
MI & $2,941,383$ & $2,998,378$ & $3,252,009$ & $3,221,028$ \\
MTs & 340,156 & 964,466 & $1,117,159$ & $1,857,277$ \\
MA & 93,840 & 314,041 & 394,678 & 441,034 \\
PTAI & 28,122 & 88,922 & 152,869 & 150,898 \\
Maddin & & $1,633,638$ & $2,314,071$ & $2,204,645$ \\
Ponpes & & 913,739 & $1,657,721$ & $1,626,447$ \\
Total & $3,403,501$ & $6,914,184$ & $8,988,507$ & $9,501,321$ \\
\hline
\end{tabular}

Source: tabulated from Data Statistik Direktorat Jendral Pembinaan Kelembagaan Agama Islam Departemen Agama Republik Indonesia tabun 1988, 1992 and 2000 and also from Anwar, Pemikiran dan Aksi Islam Indonesia.

Explanation:

PTAI : (Perguruan Tinggi Agama Islam/Islamic Tertiary Education)

Maddin : (Madrasah Diniyah/Islamic Religious School)

Ponpes : (Pondok Pesantren/Islamic Boarding School)

Besides the growing numbers of educated people, the universities in Indonesia in the 1970s also played an important role in promoting "cultural Islam." Unlike the situation in the 1950s and 1960s, when Indonesia's national universities became the centre of secular

36 Zamakhsyari Dhofier, "Lembaga Pendidikan Islam dalam Perspektif Nasional," Prisma, Number 9 (September 1983), pp. 13-20, as quoted by Anwar, Pemikiran dan Aksi Islam Indonesia, pp. 117 - 118. 
nationalism, the 1970s saw a rapid growth of Muslim student movement in the national universities. The "Salman Movement" at Institute Teknologi Bandung (ITB/Bandung Institute of Technology) was the first model of this movement. ${ }^{37}$ These so-called "Salman students", referring to the activists of Salaman mosque in ITB, rejected the scholastic argument of traditionalist Islam and the exclusivism of modernism. In order to Islamize the secular university, they adopted relaxed, democratic forms of dress, amusement, and interaction, while encouraging strict adherence to Muslim devotional acts (ibädab), including the daily prayers, the fast, and the payment of alms (zakäb) to the poor. ${ }^{38}$

The model of this campus-wide devotional movement was developed at the Mosque Salman at ITB under the guidance of M. Imaduddin Abdurrahim, a charismatic intellectual who years later would play a central role in the establishment of Ikatan Cendekiawan Muslim Indonesia (ICMI/the Association of All-Indonesian Muslim Intellectuals). Conducting an extensive campaign of religious outreach, the Salman Mosque Committee invited pop bands to play at the mosque yards, sponsored seminars on religion and development, published a small journal of culture and economic affairs, and developed a variety of educational and economic programs for poor residents living near the universities.

In Java, Salman-inspired religious activities had become a conspicuous feature of campus life at every major university by the early 1980s. The movement also led to the formation of discussion groups that sought to formulate Muslim political and economic policies. A few of these smaller groupings provided the nucleus for the more radical Islamic movement that attracted public attention and support in the 1980s and 1990s. ${ }^{39}$

Another important factor that influenced the dynamic of religious life (cultural Islam) and influenced the emergence of religious study clubs among Muslim students was the restriction of student

37 For a detailed study of the Salman movement, see Azyumardi Azra, Esei-esei Intelektual Muslim dan Pendidikan (Jakarta: Logos, 1998) pp. 61-70; Abdul Aziz, Imam Tholkhah, Soetarman (eds.), Gerakan Islam Kontemporer di Indonesia (Jakarta: Pustaka Firdaus, 1994).

${ }^{38}$ Hefner, "Islam, State and Civil Society," p. 13.

${ }^{39}$ Ibid. 
organizations and activities in campus. When Daud Yusuf became the Minister of Education and Culture in 1978, the government restricted student political activities by issuing the so-called Normalisasi Kebidupan Kampus dan Badan Koordinasi Kampus, Badan Koordinasi Kegiatan Kemahasiswaan (NKK/BKK, Normalization of Campus Live, Campus Coordination Body, Coordination Body for Students Activity). This policy was intended to force the student back to the scholarly and intellectual activities and keep them away from political practise activities. As a result, the student organizations on Campus, such as the Student Senate and the Student Representative Council, did not work properly.

This condition also gave rise to the weakening of the institutional capacity of the existing extra campus student organizations, including HMI and PMII (or Pergerakan Mahasiswa Islam Indonesia/Indonesian Muslim Student Movement). One positive consequence of this condition was the emergence of a new direction in student activity, namely from political to intellectual activity. Study groups concentrating on Islamic discussion and Islamic propagation activity in the form of the so-called "usrah movement" became a new alternative. ${ }^{40}$

The intellectual and religious dynamics were at the forefront during the 1980s. This was indicated by an increased publication of religious books, seminars, and speeches on religious themes. Various religious activities were carried out on campuses. The mosque as a place for Muslim to perform religious worship became overloaded. Islamic learning (pengajian) was intensively established in state or private offices, and many hotels conducted fashion shows of Islamic dress.

The intellectual dynamic through the increased publication of Islamic books, as indicated above, can be clearly seen in Tempo's survey. The survey was done by the division of Library and documentation of this weekly news magazine, which concluded that the printed materials in the 1980s indicated the more rising religious study. From the 7,241 books collected by Tempo since 1980, 1,949 books of them discuss religious themes. $70.5 \%$ or 809 of the above amount are Islamic books, which are written by Indonesian writers or are translated from foreign

40 As concluded from the interviews with Azyumardi Azra, Jakarta, 27 August 2000; and Bahtiar Effendy, Jakarta, 28 August 2000. 
Muslim or non-Muslim writers. ${ }^{41}$ What is interesting to note here is that the Tempo editors reported that the increased publication of Islamic books could stimulate intellectual discourse in Indonesia. The publication was initiated by the younger generation, and its results were quantitatively and qualitatively something to be proud of. ${ }^{42}$

The intellectual activities in the 1980s were also coloured by the increase in seminars and intellectual dialogues between Muslims and other religious adherents. Dialogues were promoted by Muslim and non-Muslim scientists in many centres of education and in many cities in Indonesia. An intensive dialogue, in either formal or informal forms, was also carried out between Nahdlatul Ulama (NU) and Muhammadiyah, especially among their older and younger generation. The dialogue had a significant impact on their intellectual development. In this case, Wahid had an important role, for example, in motivating the emergence of young Muslim intellectuals affiliated with NU. 43

As a continuing phase, the development of Muslim intellectuals in the 1990s cannot be separated from the features of Muslim intellectuals in the previous decades. This development was particularly in connection to the relation between Islam and the New Order government during the period of 1966-1990. From the beginning of the New Order government (1966) to the 1970s, the interaction between Islam and the government was characterised by the so-called "hegemonic relation". ${ }^{44}$ This period witnessed the ideological and political domination of the government. The government outlined that modernization was the only and best alternative to solve the problem of national decline.

Some old leading Muslim intellectuals appeared to be opposed to the concept of modernization. This reactive response caused a tension between Islamic community and the New Order government.

\footnotetext{
${ }^{41}$ Nico J. Tampi, Trend Bacaan 1980an: Cermin Meningkatnya Telaah Keagamaan (Jakarta: Majalah Tempo, 1987), as quated by Anwar, Pemikiran dan Aksi Islam Indonesia, pp. 124-125.

42 Editor, 14 Mai 1988, as quated by Anwar, Pemikiran dan Aksi Islam Indonesia, p. 125.

${ }^{43} \mathrm{He}$ was described as "cultural breaker" between traditionalist Muslim, modernist, secular and non-Muslims. See Ihsan Ali Fauzi, "Pemikiran Islam Indonesia decade 1980an," Prisma (3 March 1991), p. 39.

${ }^{44}$ This term is borrowed from Anwar. See Anwar, Pemikiran dan Aksi Islam Indonesia, especially p. ix.
} 
Witnessing this negative effect, many of the younger generation of Muslim intellectuals tried to respond to it in other ways. They demonstrated a pro-active response to the modernisation program of the New Order government. 45 Those younger Muslim Intellectuals chose a cultural approach in presenting their interest rather than a political one.

The 1980s evidenced another form of relation, which M. Syafii Anwar called it a "reciprocal relation". 46 This form of interaction was reflected by a growing mutual understanding between Islamic community and New Order government. This reciprocal relation was the result of cultural strategy expressed and supported by some Muslim intellectuals. They showed their pro-active response to the government's development program and did not directly involve themselves in political parties. They preferred to join the government system. This better relation was said by "the great majority of Muslim intellectuals" - borrowing Hefner's phrase -47 to be an unintended consequence of the Islamic organization's acceptance of the government policy to promote "Pancasila" as a sole foundation (asas tunggal) for all political and social organizations.

The significant change was seen in the 1990s, when Islam and the government respectively accommodated the interest of each other. Soeharto as the president became a central figure, and his centralistic policy can be taken therefore as an indicator of the relation between Islam and government in Indonesia. What can be seen in the 1990s is that Soeharto was more prepared to accommodate Muslim interests. According to Ramage, this is due to both the Islamic acceptance of asas tunggal and the fact that Soeharto needed Islamic support to compensate for decreased backing from the armed forces. Another reason could be personal. Soeharto may genuinely have felt closer to

\footnotetext{
45 See for further discussion Muhammad Kamal Hasan, Muslim Intellectual Response to "New Order" Modernisation in Indonesia (Kuala Lumpur: Dewan Bahasa dan Pustaka, Kementerian Pelajaran Malaysia, 1980). This work has been translated into Indonesian. See Muhammad Kamal Hasan, Modernisasi Indonesia: Respon Cendekiawan Muslim, transl. by Ahmadie Thaha (Jakarta: Lingkaran Studi Indonesia, 1987).

46 Anwar, Pemikiran dan Aksi Islam Indonesia, p. x.

${ }^{47}$ Hefner, "Islam, State and Civil Society," p. 11.
} 
religion. Many Indonesians allow that it is natural as person ages for him or her to become more religiously devout. ${ }^{48}$

Evidence of the mutual accommodation between the government and Muslim ummah, as described by Hefner, are two pieces of legislation initiated by Soeharto:

First, Law no. 7 passed by the DPR in 1989 concerned "religious court law". Ramage argued that it was not so much new law, but a clarification and reaffirmation of the independence and equality of religious (Islamic) courts of law (that deal with family, divorce, and inheritance matters) with civil courts. ${ }^{49}$ Second, Law no. 2, 1989 on the national education system affirmed the continuance of religious education in public schools and recognized religious education as a formal subsystem to the national education system. It stipulated that religious instruction was to be compulsory in all public schools and universities. ${ }^{50}$

More evidence can be seen through three other important cases. They include the government's support of the establishment of ICMI in 1990, the Joint Decree between the Minister of Internal Affairs and the Minister of Religious Affairs in 1991 that regulates the effectivity of collecting rakass and the Decree of the Directorate General of Elementary and Secondary Education of the Minister of Education and Culture that regulates and permittes the use of jilbab52 for female students. ${ }^{53}$

The accommodation of Muslim interests by the government was the result of Muslim intellectuals' clarification in a rational way of the

48 Douglas E. Ramage, Politics in Indonesia: Democracy, Islam and the Ideology of Tolerance (London: Routledge, 1995), p. 78.

49 Ibid., p. 86.

50 The religious education law was technically neutral with regard to faith -it would allow religious instruction in all faith in government schools. See, ibid., p. 86.

51 The yearly religious tax required of all Muslims as part of their religious obligations. The tax is voluntarily in Indonesia and is usually given to the poor through a committee.

${ }^{52}$ Head covering worn by some Muslim women to cover all the head except the oval of the face. It has become popular in Indonesia over the past twenty years, especially among purist groups, who regard it as a sign of piety.

53 Anwar, Pemikiran dan Aksi Islam Indonesia, p. 12. See also Studia Islamika, Vol. 2, No. 1 (1995), p. 209. 
national ideology of Pancasila, and that of the integration between Islam and Indonesia's state. Those Muslims intellectuals explained that the goal of the state was not contradicted with Islam, and that Pancasila is compatible with Islam. The explanation influenced the attitude and the policy of the government toward Islam. According to Mordiono, the cabinet's secretary of the Soeharto government, the thought of Muslim intellectuals on Islam-state ideology issues "has contributed, in the conceptual manner, to the necessity of strengthening the relation between government and Islamic ummab" ${ }^{54}$

\section{The Educational Background of Muslim Intellectuals}

The educational background of Indonesian Muslim intellectuals in the last three decades of the twentieth century can be mainly classified into two sorts. First is a sort of educational background confirming that some Muslim scholars received their education in public educational institutions, such as SMP, SMA, and University. Second is a sort of educational background which suggests that some other Muslim intellectuals received their education in Islamic educational institutions, such as MTs, MA, and Islamic Tertiary Education.

Muslim intellectuals who had completed their education in public educational institutions usually have a santri family background. From the beginning they received religious influence and religious experience from their family. In addition, they attended a religious teaching in the Madrasab Diniyah, a formal education that implements a grade system, has a certain curriculum for a certain class, and adopts evaluation system like other schools at the end of the academic term. Most of the curricula are religious sciences. The class is usually held at the afternoon.

Even, some of those Muslim intellectuals who had completed their education in public educational institutions associated with a certain pesantren (Islamic boarding school). They may come from an elite family or, in Javanese case, from priyayi (nominal Muslim) family who express religiously less devout practices than santri (committed Muslims). They were actively involved, however, in Islamic student associations during their study at tertiary education, such as HMI. For its activism during the 1960s and 1970s, HMI became the leading university Islamic student movement. It was a supporter of the

\footnotetext{
${ }^{54}$ Mordiono, "Umat Beragama dan Negara Nasional," article for Symposiom "Festival Istiqlal 1991”, as quoted by Anwar, Pemikiran dan Aksi Islam Indonesia, p. 238.
} 
Soeharto government in its crucial first years, and for this reason it rallied other larger Muslims to support the government.

Some others of Muslim intellectuals associated with PMII, an extra campus student organisation founded in the 1960s with a certain level of affiliation with the NU. Although it was declared in 1972 as an independent student organization, PMII's cultural presentation has been closely related to the NU as clearly suggested at the first time of its inception. This student organization has strong, loyal supporters especially at IAIN campuses.

Such a wide range of Muslim intellectuals with different organisational affiliations communicated to each other, both personally and organisationally. This way of interaction resulted in the growing intention among them to become devout Muslims by learning more about Islam. The success of attaining extensive knowledge in their fields in public educational institutions, combined with the religious understanding gained from their involvement in Islamic student organizations and interaction with other devout Muslims, coloured their existence as Muslim Intellectuals. After graduating, they directly involved themselves in the social activities and in the production of knowledge.

Another form of education that Muslim intellectuals have undertaken is the one provided by Islamic educational institutions. Most of these Muslim intellectuals come from santri families, therefore their parents wanted to maintain the santri attitude of their family. Besides attending the school or Islamic higher learning institutions, they were also involved actively in student organizations, intra and extra campus. These activities made it possible for them to communicate with other students affiliated with the so-called public educational institutions.

Through such a kind of interaction, they could have an advantage of being engaged in the transfer of knowledge, of getting common knowledge and of becoming more interested in learning not only religious sciences but also non-religious topics. They deepened their non-religious knowledge through self-learning. The student organizations usually hold discussions and seminars on current themes, both religious and nonreligious, which are oriented to the public interest.

As an Islamic higher learning institution in Indonesia, IAIN specifically has had a significant contribution to the emerging of Indonesian Muslim intellectuals. Historically, the embryo of IAIN was 
initially developed from Akademi Dinas Ilmu Agama (ADIA/Government Academy for religious Studies) and Perguruan Tinggi Agama Islam Negeri (PTAIN/the State Islamic Higher Education). ADIA was founded in Jakarta in 1957 and was intended as a training college for officials of the Ministry of Religious Affairs in government service and for religious teachers in state schools. PTAIN originated from the faculty of Theology at Indonesian Islamic University (UII) in Yogyakarta. On 12 August 1950, this faculty was separated from UII and taken over by the government. On 26 September 1951, it was officially re-opened under the name of PTAIN. In 1960 the PTAIN and ADIA were united to form the IAIN under the supervision of the Ministry of Religious Affairs.

The establishment of Islamic higher educational institutions, including PTAIN and ADIA, was both for political and academic reasons. In terms of politics, the founding of these Islamic higher educational institutions was an outcome of the response of Muslim groups to the government dominated by secular groups. Academically, the establishment of these institutions were intended to provide an alternative to a secular higher education. The Muslims felt that they were abandoned by the government which only supported the creation of general universities without any faculty of Islamic Studies. This encouraged some Muslims to build private Islamic higher educational institutions in order to provide Muslim community with educational services and to disseminate the teachings of Islam.

Al-Azhar University in Cairo had indeed been an inspirational model for the architects of IAIN across Indonesia. The IAIN Jakarta and IAIN Yogyakarta, as the two oldest among others and now transforming themselves into the Universitas Islam Negeri or UIN (the State Islamic University), have developed into institutions that in many ways are much broader than al-Azhar. It was not until the 1970s that a serious, but gradual, process of reform saw the transformation of the IAIN into institutions that combined traditional Islamic scholarship with a modern approach in learning. But even in the late 1960 s significant individual members of staff, such as Nasution at the IAIN Jakarta and Ali at the IAIN Yogyakarta, were exerting a progressive influence on certain students, pushing them to think through the basis of their convictions and to approach the study of Islam in a critically 
informed fashion. Under their leadership, IAIN created a postgraduate program that produced many highly educated Muslims. ${ }^{55}$

Compared with other graduates, the alumni of IAIN or other Islamic education institutions have at least two important specifications. First, they have knowledge of religious science that gives them self-confidence. Second, because they also informally study a "nonreligious science" or "general science", they are also knowledgeable in general sciences. In discussing the problem of modernization, for example, they use modern idioms. The alumni of public educational institutions, on the other hand, do not have such self-confidence when discussing the problem of religion. In discussing social, political and economic problems in Indonesia, for example, one cannot ignore their relation with Islam. Thus, the alumni from IAIN are more vocal and easier to understand when they discuss and analyse the social, religious, and political problems than the alumni from other institutions. ${ }^{56}$ Currently, Madjid, Azyumardi Azra, and Komaruddin Hidayat are among those who represent the alumni of IAIN and other religious education institutions; who have become authoritative Muslim intellectuals and dominate Islamic discourses in Indonesia. ${ }^{57}$

The government has an important role in maintaining cooperation between educational institutions. For the purpose of furthering better quality of education in IAIN, for example, the Directorate of Higher Islamic Education Institutions of the Ministry of Religious Affairs has taken some important measures in order to anticipate further challenges. One measure is sending IAIN lecturers to Western and

55 For further discussion about IAIN, see "Empowering Islamic Higher Education Institutions," Studia Islamika, an additional information, Vol. 4, No. 3 (1997), p. 3; B.J. Boland, The Struggle of Islam in Modern Indonesia (The Hague: Martinus Nijhoff, 1982), pp. 120-123; Mastuki HS., "Tatłwwur al-Ta lił al-'Ali Indonesia," Studia Islamika, Vol. 4, No. 3 (1997), p. 172; Barton, "Indonesia's Nurcholish Madjid and Abdurrahman Wahid," p. 328.

${ }^{56}$ Interview with Komaruddin Hidayat, Jakarta, 25 August 2000.

57 In the 1980s, there was criticism of the IAIN graduates. IAIN graduates were perceived as being unable to fulfil their role when rural people are being urbanized, the agrarian economic system is being replaced by an industrial one, and traditional leadership is being marginalized by modern one. The task of explaining Islam from a modern point of view has been undertaken by Indonesian Muslim social scientists, who begun to return from their studies at Western universities. They occupied Islamic discourses on university campuses and in the community in general. See "Intellectual Engineering in IAIN,” p. 3. See also Ramage, Politics in Indonesia, pp. 77-78. 
Middle Eastern countries to undertake post-graduate programs in various fields of study. They are financially supported by the Ministry of Religious Affairs or the host government through a joint scheme in educational programs. Some lecturers have also been sent to other Indonesian universities, while the rest are obliged to undertake postgraduate programs at IAINs themselves. ${ }^{58}$

Bahtiar Effendy from the UIN Jakarta said that the extra campus organization has made a significant contribution to the formation of students' concern of the intellectual activity. At the end of the 1970s, for example, student activists, including Effendy, Komaruddin Hidayat, Azyumardi Azra, Fachry Ali, Hadimulyo, and A. Rifa'i, conducted discussions every Wednesday at the Lembaga Penelitian, Pendidikan dan Penerangan Ekonomi dan Sosial (LP3ES/Institute for the Research, Education, and Information on Economy and Society) ${ }^{59}$ Jakarta under the guidance of Rahardjo, the director of this institute at that time. This kind of activity could enlarge the intellectual perspective of IAIN students especially in the field of social sciences and made it possible for them to be directly engaged in social research, social work, and social advocacy. ${ }^{60}$

The study clubs which emerged in the middle of the 1980s in Jakarta also contributed to the formation of students' intellectual engagement. Many students joined study clubs such as Formaci, Piramida Circle, and Forum Studi Lingkaran. The reason they preferred to join study clubs rather than student organizations was due to their disappointment with the extra campus student organization activities which especially in 1985 did not emphasize intellectually oriented activities. ${ }^{61}$ The organizations concentrated merely on recruiting as many new cadres as possible. According to Azra, the reason for the emergence of study clubs in the middle of the 1980s was the assumption that the existing extra campus student organizations, such

\footnotetext{
${ }^{58}$ For further information see "Intellectual Engineering in IAIN," pp. 1-6.

59 LP3ES was established in 1971 as a further development of a project that was sponsored by Friedrich Naumann Stiftung (FNS), Germany. The project was begun in 1969. See, Martin van Bruinessen, NU, Tradisi, Relasi-relasi Kuasa dan Pencarian Wacana Baru (Yogyakarta: LKiS, 1994), p. 236.

${ }^{60}$ Interview with Bahtiar Effendy, Jakarta, 28 August 2000; Interview with Azyumardi Azra, Jakarta, 27 August 2000; Interview with Komaruddin Hidayat, Jakarta, 25 August 2000.

${ }^{61}$ Interview with Bahtiar Effendy, Jakarta, 28 August 2000.
} 
as HMI, PMII or IMM (Ikatan Mahasiswa Mubammadiyah/the Association of Muhammadiyah Student) were too late in responding to the idea of Islamic movement after the Iranian revolution. There was a euphoric enthusiasm over the success of Iran in opposing the United States. For this reason many students established study clubs which were oriented to discuss intellectually the idea of Islam and society. ${ }^{62}$ They were not interested with non-intellectually oriented activity of student organizations. ${ }^{63}$

The same form of student's affiliation with organization and study clubs also emerged in Yogyakarta. The principle difference is the time when the students joined the study clubs. They began to join or to establish study club after they could no longer be affiliated with student organizations. In order to accommodate their potentiality of activism and intellectualism, they established an institution or joined an existing institution immediately after they graduated. LKiS (Lembaga Kajian Islam dan Sosial/the Institute for Islamic and Social Studies) in Yogyakarta was established in 1989 in this way. At first, this institution was an informal study group consisting of students from IAIN, UII, and UGM (State Gajah Mada University). Because of the need of management and the dissemination of information and knowledge and specifically because of the need to build LKiS as a formal institution, it was then declared as a non-profit foundation. ${ }^{64}$ This foundation has promoted a number of intellectual activities.

In Surabaya, the student activists, especially activists of PMII, also tried to associate in a study forum called Gerbang (founded in 1993). This forum consisted of Airlangga University and IAIN Sunan Ampel students. Their first contact began from their activity in the student press. When they finished studying, they continued their intellectual activity by promoting a new institution called èLSAD (Lembaga Studi Agama dan Demokrasi/the Institute for the Study of Religion and Democracy). It was oriented toward studying the relation of religion and democracy by conducting research and through discussions and publications. They published Gèrbang, a journal on religion and democracy. This journal was acknowledged by Muhammad AS Hikam

\footnotetext{
${ }^{62}$ Interview with Azyumardi Azra, Jakarta, 27 August 2000.

${ }^{63}$ Interview with Bahtiar Effendy Jakarta, 28 August 2000.

${ }^{64}$ Unpublished pamphlet of LKiS.
} 
as a "high intensity" periodical publication. ${ }^{65}$ Hikam also rendered the activist of èLSAD, as well as other young intellectuals within NU, as people with a "hybrid culture", a culture being based not only on the traditional sources of Islam but also on the other. ${ }^{66}$

\section{Conclusion}

From the above discussion, it can be concluded that three important factors influenced the emergence of Indonesian Muslim Intellectuals in the 1970s and 1980s. First was the publicly rising Islamic thought renewal movement promoted by scholars, including Madjid, Nasution, and Ali. Second was the increasingly intense sociopolitical relation between the government and the Muslim community during the New Order period. Third was the success story of education as well as the socio-political and academic activities of the Muslim student movement. Nevertheless, the most dominant factor among those three was the third one. The vertical mobility of Muslims in social and political institution, as shown in the 1990s, was a result of their success in education.

Four sorts of Muslim intellectuals with their own organisational affiliation appeared clearly in the last three decades of the twentieth century during their study at universities. First was a sort of Muslim intellectuals whose academic grades were good and were actively engaged in the student organisation in campus. Second was a kind of Muslim intellectuals who were actively engaged in extra campus student organisations, such as HMI and PMII. Third was a type of Muslim intellectuals whose academic activity during their study at university centred around the discussion clubs. They formed a discussion forum that consisted of student from various universities along with their different subject of studies. Fourth was a sort of Muslim intellectuals who were actively engaged in all intra or extra campus student organisations in addition to many discussion clubs. []

\footnotetext{
${ }^{65}$ Interview with Muhammad AS Hikam, Jakarta, 16 July 2000.

${ }^{66}$ Muhammad AS Hikam, "Anak Muda NU, Kultur Hibrid dan Negara," in Kultur Hibrida: Anak Muda NU di Jalur Kultural, ed. by Hairus Salim HS and Muhammad Ridwan (Yogyakarta: LKiS, 1999), pp. 259-260.
} 


\section{Bibliography}

\section{Books and Articles}

"Empowering Islamic Higher Education Institutions." Studia Islamika, an additional information, Vol. 4, No. 3 (1997): pp. 1-6.

Anwar, M. Syafi'i. Pemikiran dan Aksi Islam Indonesia: Sebuab Kajian Politik tentang Cendekiawan Muslim Orde Baru. Jakarta: Paramadina, 1995.

Aqsha, Darul, Dick van der Meij, and Johan Hendrik Meuleman (eds.). Islam in Indonesia: A Survey of Events and Developments from 1988 to March 1993. Jakarta: INIS, 1995.

Aziz, Abdul, Imam Tholkhah, Soetarman (eds.). Gerakan Islam Kontemporer di Indonesia. Jakarta: Pustaka Firdaus, 1994.

Azra, Azyumardi. Esei-esei Intelektual Muslim dan Pendidikan. Jakarta: Logos, 1998.

Barton, Greg. "Indonesia's Nurcholish Madjid and Abdurrahman Wahid as Intellectual Ulama: The Meeting of Islamic Traditionalism and Modernism in Neo-Modernist Thought, Islam and Christian-Muslim Relation." Studia Islamika. Vol. 8, No. 3 (1997): p. 325.

-------. Gagasan Islam Liberal di Indonesia. Jakarta: Paramadina, 1999.

Boland, B.J. The Struggle of Islam in Modern Indonesia. The Hague: Nijhoff, 1982.

Booth, Anne. "Repelita V and Indonesia's Medium-term Economic Strategy." Prisma, Number 48 (December 1989): pp. 16-17.

Bruinessen, Martin van. NU, Tradisi, Relasi-relasi Kuasa dan Pencarian Wacana Baru. Yogyakarta: LKiS, 1994.

Brym, Robert J. Intellectuals and Politics. London: Goerge Allyn and Unwin, 1980.

Coser, A. Lewis. Men of Ideas. New York: London, 1965.

Dhofier, Zamakhsyari. "Lembaga Pendidikan Islam dalam Perspektif Nasional." Prisma, Number 9 (September 1983): pp. 13-20.

Effendi, Djohan and Ismet Nasir (eds.). Pergolakan Pemikiran Islam, Catatan Harian Abmad Wabib. Jakarta: LP3ES, 1995. 
Fauzi, Ihsan Ali. "Pemikiran Islam Indonesia decade 1980an." Prisma. (3 March 1991).

Hasan, Muhammad Kamal. Modernisasi Indonesia: Respon Cendekiawan Muslim. transl. by Ahmadie Thaha. Jakarta: Lingkaran Studi Indonesia, 1987.

---------. Muslim Intellectual Response to "New Order" Modernisation in Indonesia. Kuala Lumpur: Dewan Bahasa dan Pustaka, Kementerian Pelajaran Malaysia, 1980.

Hefner, Robert W. "Islam, State and Civil society: ICMI and the Struggle for Indonesian Middle Class." Indonesia, No. 56 (October 1993): pp. 1-35.

Hikam, Muhammad AS. "Anak Muda NU, Kultur Hibrid dan Negara." in Kultur Hibrida: Anak Muda NU di Jalur Kultural. ed. by Hairus Salim HS and Muhammad Ridwan. Yogyakarta: LKiS, 1999. pp. 259-260.

HS, Mastuki. “Tatłwwur al-Ta lim al-Ak>bi Indonesia." Studia Islamika, Vol. 4, No. 3 (1997): pp. 171-218.

Madjid, Nurcholish. Islam, Kemoderenan dan Keindonesiaan. Bandung: Mizan, 1995.

Mudzhar, Muhammad Atho'. Fatwas of the Council of Indonesian Ulama: A Study of Islamic Legal Thought in Indonesia (1975-1988). Jakarta: INIS, 1993.

Panitia Penerbitan Buku dan Seminar 70 Tahun Harun Nasution. Refleksi Pembaharuan Pemikiran Islam. Jakarta: LSAF, 1989.

Rahardjo, M. Dawam. Intelektual, Intelegensia dan Prilaku Politik Bangsa. Bandung: Mizan, 1993.

Ramage, Douglas E. Politics in Indonesia: Democracy, Islam and the Ideology of Tolerance. London: Routledge, 1995.

Rasyidi, M. Koreksi terbadap Drs. Nurcholish Madjid tentang Sekularisasi. Jakarta: Bulan Bintang, 1972.

Ridwan, M. Deden. "Tempo dan Gerakan Neo-Modernisme Islam Indonesia.” Ulumul Quran, No. 3, Vol. VI (1995): pp. 56-57.

Shils, Edward. "The Intellectuals in Political Development of the New States." in Jason L. Finkle and Richard W. Gable (eds.). Political Development and Social Change. New York: London, 1971. 
Khoirun Niam

Tampi, Nico J. Trend Bacaan 1980an: Cermin Meningkatnya Telaah Keagamaan. Jakarta: Majalah Tempo, 1987.

\section{Newspapers}

Editor (Weekly News), 14 March 1992.

Editor (Weekly News), 14 May 1988.

Tempo (Weekly News), 29 July 1972.

\section{Interviews}

Interview with Azyumardi Azra, Jakarta, 27 August 2000.

Interview with Bahtiar Effendy, Jakarta, 28 August 2000.

Interview with Dawam Rahardjo, Jakarta, 24 August 2000.

Interview with Komaruddin Hidayat, Jakarta, 25 August 2000.

Interview with Muhammad AS Hikam, Jakarta, 16 July 2000. 